Review

\title{
Obesity, Body Image Dissatisfaction, and Sexual Dysfunction: A Narrative Review
}

Sean M. McNabney ${ }^{1,2}$

check for

updates

Citation: McNabney, S.M. Obesity,

Body Image Dissatisfaction, and

Sexual Dysfunction: A Narrative

Review. Sexes 2022, 3, 20-39. https://

doi.org/10.3390/sexes3010002

Academic Editor: Angelo Cignarelli

Received: 6 October 2021

Accepted: 4 January 2022

Published: 6 January 2022

Publisher's Note: MDPI stays neutral with regard to jurisdictional claims in published maps and institutional affiliations.

Copyright: (C) 2022 by the author Licensee MDPI, Basel, Switzerland. This article is an open access article distributed under the terms and conditions of the Creative Commons Attribution (CC BY) license (https:// creativecommons.org/licenses/by/ $4.0 /)$.
1 Department of Applied Health Science, School of Public Health, Indiana University, Bloomington, IN 47405, USA; smmcnabn@iu.edu

2 Center for Sexual Health Promotion, Indiana University, Bloomington, IN 47405, USA

\begin{abstract}
With approximately two-thirds of the United States adult population classified as overweight or obese, obesity remains a critical public health concern. Obesity not only contributes to several health complications including type 2 diabetes mellitus and cardiovascular disease, but the condition is also associated with sexual dysfunction in both women and men. Despite evidence linking obesity and its concomitant pathophysiology to sexual problems, the potential roles of psychosocial factors such as body image are understudied. This narrative review evaluates the research linkages between obesity and sexual dysfunction, with particular attention to the potential effects of body image dissatisfaction. A literature search of biomedical and psychological databases was used to identify research pertaining to obesity, sexual function, and/or body image constructs. The pathophysiological effects of obesity on sexual function are well-documented in mechanistic studies and animal trials, often with corroboration in human clinical samples. However, very few studies examine obesity, body image, and sexual function in tandem. Body image dissatisfaction appears to independently impinge upon the sexual response cycle and mental health outcomes, irrespective of body weight. While obesity is often associated with negative body image appraisal, it is unclear whether these constructs exert additive, synergistic, or antagonistic effects on sexual responsivity. Additionally, overweight/obese individuals who exhibit higher levels of body image satisfaction or self-confidence appear to be protected from the deleterious effects of obesity on sexual satisfaction, at least to some extent. Greater reliance upon conceptual/theoretical models from the body image literature may better clarify the relationships between these constructs.
\end{abstract}

Keywords: obesity; diabetes mellitus; sexual health; sexual arousal; body image

\section{Introduction}

Despite educational programming on the deleterious effects of excess body weight, the prevalence of obesity in the United States remains high [1,2]. Drawing upon body-mass index (BMI) data from the National Health and Nutrition Examination Survey (NHANES), Hales and colleagues noted a 5.9\% increase in the age-standardized obesity prevalence among adults between the 2007-2008 and 2015-2016 interview periods [1]. Within the study population $(n=27,449), 37.9 \%$ of men and $41.1 \%$ of women were classified as obese $\left(\mathrm{BMI} \geq 30 \mathrm{~kg} / \mathrm{m}^{2}\right)$ in 2015-2016 [1]. Additionally, 9.7\% of women and $5.6 \%$ of men were categorized as severely obese $\left(B M I \geq 40 \mathrm{~kg} / \mathrm{m}^{2}\right)$ [1]. Data from the 2017-2018 collection period also revealed that approximately $30 \%$ of respondents were classified as overweight $\left(B M I \geq 25 \mathrm{~kg} / \mathrm{m}^{2}\right)$ [3]. Thus, the combined prevalence of overweight and obesity exceeds two-thirds of the adult US population. Even more troubling, current projections suggest that the prevalence of obesity will continue to rise. Using data from the Behavioral Risk Factor Surveillance System (BRFSS), Finkelstein and colleagues generated logistic regression models predicting an obesity prevalence of approximately $40 \%$ by 2030 [4]. Beyond these problematic trends in the United States, multinational prevalence estimates indicate that obesity is a global health issue. Data from the Global Burden of Disease Study showed 
that approximately 1.9 billion adults were overweight and 609 million were obese in 2015, an estimated $39 \%$ of the global population at that time [5]. Obesity also contributes to healthcare expenditures, with a systematic review assessing the costs of obesity between $0.7-2.8 \%$ of a given country's healthcare budget [6]. The inclusion of overweight individuals further increased the upper threshold of this estimate to $9.1 \%$ [6], suggesting that increasing prevalence of overweight and obesity will continue to elevate medical costs worldwide. Moreover, while high-income nations tend to experience unambiguous rises in obesity, several low- and middle-income countries (LMICs) report a double burden of both obesity and undernutrition among their populations [7]. Interestingly, the development of more affordable, energy-rich (but nutrient-poor) foods places an additional burden on individuals and families below the poverty threshold in affluent countries, as more healthful food options may not be financially feasible [8]. Therefore, obesity might also be conceptualized as a structural or systemic disease in which social inequities (such as high food prices or limited healthcare access) restrict individuals' abilities to engage in health-promoting behaviors [8].

Obesity among children and adolescents is also a public health concern, with $17.8 \%$ of survey participants (ages 2-19) assessed in the NHANES 2013-2016 data collection period classified as obese (BMI-for-age $\geq 95$ th percentile per the CDC guidelines) [9]. A systematic review analyzing data from the Health Behaviour in School-Aged Children Study in 34 countries $(n=137,593)$ revealed a high prevalence of obesity among children in multiple North American and western European countries [10]. Within the United States, $25.1 \%$ of youth were classified as overweight, and $6.8 \%$ were obese [10]. Recent evidence further suggests that the presence of overweight/obesity during childhood or adolescence often persists into adulthood [11], which can exacerbate health complications over time. For example, youth-onset type 2 diabetes mellitus (T2DM) appears to be far less amenable to pharmacological interventions, even when compliance is high $[12,13]$.

Chronic obesity has been linked to several health conditions, including cardiovascular disease (CVD), hypertension, and T2DM [14-17]. Moreover, obesity and unmitigated T2DM negatively impact many of the physiological systems involved in the sexual response cycle $[18,19]$. Yet, despite the extensive data on obesity-related pathophysiology, the psychosocial implications of obesity on sexual desire/arousal and activity are understudied [20]. In particular, the effects of body image dissatisfaction on sexual functioning and relationship satisfaction are poorly understood within the context of obesity.

This review explores potential linkages between obesity, body image concerns, and sexual function, noting recent insights and opportunities for future inquiry. Five research questions helped to narrow the focus of the review (see also Table 1). First, what are the metabolic and physiologic changes that occur as a result of obesity, and to what extent do they impact the human body? Second, how can three obesity-related mechanisms (adipose tissue dysregulation, poor glycemic control, and unmitigated inflammation) impact sexual functioning specifically? Third, how can obesity influence body image appraisal and satisfaction, and could the generalizability of these research findings be confounded by general body dissatisfaction? Fourth, to what extent have obesity, body image concerns, and sexual function/sexual satisfaction been studied within the same individuals? Finally, how have social movements related to body positivity or size acceptance offered alternative accounts of the obesity-body image-sexual function/satisfaction relationship?

Table 1. Description of the primary research questions addressed in this review.

\section{Research Questions}

(1) What are the general pathophysiological effects and mechanisms of action for obesity?

(2) How do obesity-mediated mechanisms impact sexual function specifically?

(3) To what extent does obesity influence body image satisfaction and appraisal?

(4) To what extent have obesity, body image, and sexual function been studied in tandem?

(5) How have social movements (e.g., body positivity) characterized obesity and sexuality? 


\section{Methods}

Literature searches were performed by the author between May 2021 and November 2021 using the following databases: PubMed, MEDLINE with Full Text, APA PsycArticles, and Academic Search Complete/EBSCO. Articles were generally restricted to those published in English and after the year 2000. However, older publications were included when they provided a significant historical context or research paradigm (e.g., foundational work on the human sexual response cycle). Table 2 illustrates key terms that were used during the search process. The Boolean operators AND, OR, and NOT were also used to refine searches.

Table 2. Key terms from literature searches.

\begin{tabular}{|c|c|c|c|}
\hline $\begin{array}{c}\text { Obesity/Health } \\
\text { Terms }\end{array}$ & $\begin{array}{l}\text { Subject } \\
\text { Terms }\end{array}$ & $\begin{array}{c}\text { Sexual Health } \\
\text { Terms }\end{array}$ & $\begin{array}{c}\text { Body Image } \\
\text { Terms }\end{array}$ \\
\hline Overweight & $\operatorname{Human}(\mathrm{s})$ & (Sexual) desire & Body image \\
\hline Obese & Women & (Sexual) arousal & Body (dis)satisfaction \\
\hline Obesity & Female & Orgasm & Body appreciation \\
\hline Diabetes (mellitus) & Men & Ejaculation & (Body image) appraisal \\
\hline Insulin resistance & Male & (Vaginal) lubrication & Weight stigma \\
\hline Adipose (tissue) & Rodent & Erection & Anxiety \\
\hline Adipocyte(s) & Murine & Sexual satisfaction & Depression \\
\hline Inflammation & & (Sexual) pleasure & Fat acceptance \\
\hline \multirow[t]{2}{*}{ Glycemia } & & (Sexual) pain & Body positivity \\
\hline & & & Health at every size \\
\hline
\end{tabular}

Although this narrative review did not incorporate a stringent set of inclusion/exclusion criteria, publications that were considered for inclusion typically met at least one of the following criteria: (1) evaluated obesity in the context of physiological or psychological outcomes; (2) included sexual functioning, sexual health, or sexual satisfaction as an outcome variable or predictor/covariate in the analyses; (3) examined the effects of obesity on body image satisfaction or appraisal, ideally assessed at multiple time points; and (4) when possible, used a validated instrument for sexual functioning, such as the Female Sexual Function Index (FSFI, [21,22]) or the International Index of Erectile Functioning (IIEF, [23]), rather than a unidimensional self-reported outcome. This review incorporated data from a variety of research designs, including biochemical/cell culture experiments, analyses of isolated tissue samples (e.g., murine genital epithelium), randomized animal trials, human clinical data, and qualitative studies. Due to the sheer volume and heterogeneity of the obesity research literature (see also Table A1), this review best serves as a narrative overview of the field rather than a comprehensive treatment of the subject.

\section{The Pathophysiology of Obesity}

\subsection{Obesity and Adipose Tissue Dysregulation}

Traditional models of obesity described adipose tissue as an inert storehouse of lipids with secondary roles in temperature regulation and organ cushioning [24]. Research over the previous three decades has identified several additional functions of adipose cells (adipocytes), including the synthesis and release of endocrine hormones (e.g., adiponectin and leptin) and a more prominent role in glucose homoeostasis [24,25].

The regulation of blood glucose levels involves coordinated activity between the adipose tissue, liver, and skeletal muscle [26]. When plasma glucose levels are high, insulin is synthesized and secreted from the pancreatic beta cells ( $\beta$-cells). Insulin not only stimulates glucose uptake by the skeletal muscle, but it also inhibits the breakdown of stored fat reserves within the adipocytes [27]. Ultimately, fat storage in adipocytes increases when insulin (and by extension, glucose) is plentiful [27]. In the liver, insulin stimulates the conversion of glucose into glycogen for storage, and it also reduces de novo glucose production [28]. As plasma insulin levels decrease, adipocytes increase fat breakdown 
(lipolysis) and release the resulting non-esterified fatty acids (NEFAs) into circulation to meet the energy demands of systemic tissues $[29,30]$. Lipolysis can also be stimulated by epinephrine and norepinephrine, which act upon $\beta$-adrenergic receptors on the adipocyte cell surface [29]. Through these mechanisms, glucose and fatty acid use are tightly regulated in response to nutrient availability, environmental stressors, and the hormonal milieu.

In cases of chronic overfeeding and obesity, the ability of the skeletal muscle and other systemic tissues to shift energy substrates (from carbohydrate to lipid, and vice versa) becomes impaired [31,32]. These metabolic derangements can be partially explained by insulin resistance, a condition in which higher concentrations of insulin are required to stimulate target tissues and to regulate plasma glucose levels. Over time, insulin resistance prevents adipocytes from "maximally stimulat[ing] lipolysis during fasting and maximally promot[ing] lipid storage during feeding" [27] (p. 2162), ultimately leading to higher plasma concentrations of NEFAs [33]. In an attempt to remove these excess lipids from circulation, the liver and skeletal muscle can also store free fatty acids as triacylglycerols [30]. While this strategy can prevent hyperlipidemia in the short-term, ectopic lipid accumulation ultimately reduces insulin sensitivity in the liver and skeletal muscle $[25,30]$. As a result, early interventions in overweight/obese individuals might involve preserving the lipid storage capabilities of adipose tissue and reducing lipolysis when circulating glucose levels are sufficient to meet the energy demands of other tissues [26,27].

\subsection{Obesity and Systemic Inflammation}

In addition to its detrimental effects on lipid and carbohydrate metabolism, obesity is also associated with elevated markers of inflammation. Recent evidence suggests that transient inflammation occurs during adipocyte expansion, and the release of cytokines including tumor necrosis factor alpha (TNF- $\alpha$ ) and oncostatin M is necessary for adipocyte development [25]. For obese individuals, in contrast, these pro-inflammatory signaling cascades are either poorly regulated or remain active in a persistent, low-grade state. If the inflammatory response is not properly resolved, chronic inflammation can damage other tissue types including the arterial vessels, thereby increasing the risk of atherosclerotic plaque development $[34,35]$. Longer-term inflammatory processes are also implicated in insulin resistance [36].

It is well established that adipocytes can increase both in relative size (hypertrophy) and number (hyperplasia) to accommodate greater influx of dietary lipids. In fact, the anti-diabetic thiazolidinedione medications (TZDs) stimulate adipocyte hyperplasia and increase insulin sensitivity through the action of peroxisome proliferator-activated receptor gamma (PPAR- $\gamma$ ) [29,37]. However, recent findings suggest that the capacity of adipose tissue expansion is restricted by the supporting vasculature. When adipocyte growth outpaces angiogenic mechanisms, the existing blood supply may be insufficient to deliver oxygen gas and nutrients to the adipose tissue $[25,38]$. Under these hypoxic conditions, adipocytes often undergo necrotic cell death, leading to the recruitment and infiltration of pro-inflammatory macrophages and mast cells $[28,39]$. For example, Altintas and colleagues (2011) demonstrated a significantly higher proportion of dead adipocytes in obese C57BL/6 mice fed a high-fat diet ( $60 \% \mathrm{kcal}$ from fat) compared to their lean counterparts [40]. Moreover, mice in the obese group exhibited significantly more mast cells in their visceral fat depots and greater release of TNF- $\alpha$ compared to the lean condition [40]. Other studies have suggested that inflammation may also be facilitated by an excessive accumulation of extracellular matrix (ECM) proteins [41]. These ECM proteins may also inhibit the action of pro-angiogenic molecules such as vascular endothelial growth factor (VEGF), preventing the formation of new blood vessels.

In some cases, the reported benefits of dietary and physical activity behaviors may be related to the mitigation of chronic inflammation in obese or diabetic patients. For example, adherence to an anti-inflammatory diet (operationally defined as increased consumption of low-glycemic carbohydrates, legumes, fruits and vegetables, and marine fish, with avoidance of red meat and processed foods) for six months reduced inflammatory biomarkers 
such as TNF- $\alpha$ and interleukin-6 (IL-6) in obese young adults compared to controls [42]. In contrast, consumption of a pro-inflammatory dietary pattern was associated with higher waist circumference and waist-to-height ratio compared to participants consuming an anti-inflammatory diet [43]. Interestingly, these effects occurred despite adherence to a Mediterranean-style or low-fat diet, suggesting that inflammation can independently affect body weight and metabolic parameters. For women, the BMI values were also significantly higher in the pro-inflammatory diet conditions [43]. Physical activity interventions have also demonstrated favorable changes in inflammatory markers. A prospective cohort study of older adults $(n=489$, ages 55-75) revealed that an increase in total physical activity over a 1-year period was associated with reductions in pro-inflammatory biomarkers, particularly C-peptide and leptin [44]. In a similar study, older African American adults were randomly assigned to a physical activity or physical activity and weight loss intervention for 8 weeks [45]. Both intervention groups decreased TNF- $\alpha$ levels, irrespective of weight loss, but the physical activity/weight loss combination group also experienced significant improvements to fasting insulin levels [45]. For children and adolescents, multiple physical activity interventions reduced body weight and improved insulin sensitivity [46,47], with minor improvements to inflammatory biomarkers from baseline [46]. Surgically mediated weight loss may also reduce systemic inflammation, as a sample of obese adults who underwent Roux-en- $Y$ gastric bypass surgery exhibited significantly lower levels of TNF- $\alpha$ and leptin 6 months following the operation compared to baseline, as well as to obese controls who did not receive bariatric surgery [48]. These beneficial changes were accompanied by reductions in systolic and diastolic blood pressure, total cholesterol, low-density lipoprotein (LDL) cholesterol, and fasting blood glucose [48].

\subsection{Obesity and Metabolic Inflexibility}

Along with adipocyte dysfunction and systemic inflammation, obesity is associated with metabolic inflexibility. Under optimal conditions, skeletal muscle preferentially uses glucose following digestion and absorption [31]. As insulin levels taper off and glucose levels decrease, skeletal muscle will shift to fatty acid oxidation to meet its energy requirements [29]. This transition between energy substrates can be quantified using the respiratory quotient $(\mathrm{RQ})$, which corresponds to the ratio of $\mathrm{CO}_{2}$ production relative to $\mathrm{O}_{2}$ consumption [31,32]. In cases of obesity and insulin resistance, the skeletal muscle mitochondria exhibit impaired fuel switching, oxidizing a mixture of carbohydrate and fatty acid metabolites irrespective of nutritional cues such as insulin [32]. Accumulation of $\beta$-oxidation intermediates, such as medium- and long-chain acylcarnitines, also suggests reduced mitochondrial function in the obese, insulin-resistant state [49-51]. Moreover, intramyocellular lipid droplets can interfere with mitochondrial communication to other organelles, such as the endoplasmic/sarcoplasmic reticulum [52], demonstrating yet another putative mechanism for metabolic inflexibility.

Current strategies to improve metabolic flexibility and mitochondrial function are similar to those proposed for reducing systemic inflammation. For example, both dietary supplementation of fiber/resistant starches and increased production of short-chain fatty acids such as butyrate have been associated with improved mitochondrial function and insulin sensitivity [53-56]. In addition to implementing beneficial foods, dietary regimens often involve reducing saturated fats and simple carbohydrates [42,43]. By increasing mitochondrial capacity for fatty acid oxidation, these interventions can prevent ectopic lipid deposition and its downstream effects. Exercise interventions have demonstrated particular utility, as physical activity stimulates an insulin-independent mechanism of glucose uptake by the skeletal muscle, and perhaps by the adipocytes as well [57-59]. This finding has been supported in clinical research, as overweight and obese adolescents exhibited significant improvements in glucose disposal after a 6-month intervention of aerobic exercise, resistance training, or a combination of both modalities [47]. 


\section{Obesity and Sexual Dysfunction}

Establishing a direct relationship between obesity and sexual dysfunction remains challenging for multiple reasons. First, the presentation of obesity is often heterogeneous, with some patients experiencing greater levels of metabolic dysfunction and inflammation than others. Although controversial, the classification of "medically healthy obesity" describes the presentation of obesity without concomitant metabolic dysfunction [60]. Whether metabolically healthy obesity represents a more stable classification or illustrates a prodromal state before health complications emerge is disputed [61]. Second, the etiology of obesity may differ depending upon which lifestyle factors (e.g., poor nutrition, lower physical activity) are most applicable to each individual. Certain genetic variants can also influence a person's energy intake, reduce the sensitivity of the insulin receptor, limit insulin production at the level of the pancreas, or impair oxidation of fatty acids within the mitochondria [62-64]. Third, it is difficult to experimentally control for obesity-related health complications such as insulin resistance or dyslipidemia to determine whether obesity per se has a distinct impact on sexual functioning. Lastly, research conducted with human subjects typically assesses sexual functioning by self-report in cross-sectional or quasi-experimental pre-post designs; while this information is certainly valuable, it cannot establish causal relationships between obesity and sexual dysfunction.

Despite these limitations, however, the available data suggest that obesity can negatively impact sexual functioning through all three aforementioned mechanisms. For example, changes to adipocyte physiology are not only associated with pro-inflammatory mediators, but they are also accompanied by increased expression of aromatase [65]. Since aromatase is involved in the conversion of androgens to estrogens-particularly testosterone (T) to estradiol (E2) - men with obesity or metabolic dysfunction often present with significantly lower testosterone and higher estrogen levels in circulation. Since male sexual functioning relies upon androgen activity, changes in testosterone can impact sexual desire/interest, penile erection, and even sensitivity of the penis to stimulation [24]. In women, the impact of higher estrogen levels on sexual functioning is less apparent, but persistently elevated estrogens may contribute to the growth of estrogen-dependent breast cancers $[65,66]$. Rodent models have suggested that reductions in circulating estradiol are associated with diminished expression of aquaporin proteins and nitric oxide synthase activity, both of which support female sexual responsivity [67]. Obesity in women also increases androgen availability, perhaps due to a lower expression of sex hormone-binding globulin. The extent to which androgens interfere with female sexual function is equivocal, as women presenting with polycystic ovarian syndrome (PCOS) often display higher circulating androgens, but their frequency of partnered sexual activity can be significantly higher than that of healthy controls [68]. However, these women also reported lower quality of life scores and lower scores on the arousal, lubrication, and satisfaction domains of the Female Sexual Function Index (FSFI) [68]. For both men and women, it is possible that the ratio of androgens to estrogens is significant, rather than the general concentration of testosterone or estradiol individually [24]. Future work may help to clarify these associations and provide additional mechanistic insights.

In addition to adipose tissue dysregulation, obesity can also negatively impact sexual response via insulin resistance/impaired mitochondrial fuel switching and resultant hyperglycemia. For example, Cushman and colleagues treated diabetic female mice $(\mathrm{db} / \mathrm{db})$ with vehicle (positive control) or estradiol [69]. After an 8-week treatment regimen, both groups of diabetic mice were compared to normoglycemic controls. Diabetic mice treated with estradiol exhibited significantly greater uterine and vaginal weight compared to the vehicle-treated mice and healthy controls. Moreover, preservation of the reproductive structures in the estradiol-treated mice occurred without concomitant weight loss or reduction in fasting blood glucose, suggesting that the restoration of estrogen balance was sufficient for these observed improvements [69]. Similarly, streptozotocin-injected female diabetic rats exhibited significantly higher glucose levels and lower expression of aquaporin proteins compared to controls $[70,71]$. Aquaporins are primarily responsible for water transport 
across cell membranes, and so lower aquaporin protein expression may be a contributing factor to insufficient vaginal lubrication, reported by many women with T2DM [72]. Studies in male diabetic Sprague-Dawley rats have suggested similar effects from hyperglycemia, with decreased expression of aquaporins in the prostate and seminal vesicles, accompanied by reduced secretions from both structures [73].

Finally, obesity-mediated inflammation has been strongly implicated in poor sexual functioning. The arousal phase of the sexual response cycle is characterized by elevated blood flow to the genital region (vasocongestion), which facilitates penile erection in men and engorgement of the clitoris and labia in women. Arterial blood flow increases via the activity of nitric oxide (NO), which stimulates the enzyme guanylyl cyclase to produce cyclic guanosine monophosphate (cGMP) [29]. cGMP induces relaxation of smooth muscle cells, which in turn increases the diameter of blood vessels (vasodilation) and enables greater blood flow. Indeed, the pro-erectile medication sildenafil (Viagra) prevents cGMP degradation, thereby prolonging the effects of $\mathrm{NO}$ and ultimately increasing blood flow to the penis [74]. Chronic inflammation appears to reduce expression of nitric oxide synthase, thereby lowering NO production and availability. Interestingly, recent evidence has suggested an alternative mechanism for inflammation, as obese rats exhibited greater arterial sensitivity to contractile peptides such as endothelin-1 (ET-1) [75-77]. Table 3 provides a summary of these mechanisms and their effects on the sexual response.

Table 3. The impact of obesity-related mechanisms on sexual functioning.

\begin{tabular}{cl}
\hline Pathophysiological Mechanism & \multicolumn{1}{c}{ Effects on Sexual Functioning/Response } \\
\hline Adipose Tissue Dysregulation & * Estrogen-androgen imbalance \\
& * Secretion of pro-inflammatory mediators \\
& ${ }^{*}$ Increased expression of aromatase $(\mathrm{T} \rightarrow \mathrm{E} 2)$ \\
\hline Poor Glycemic Control & $*$ Alterations to vaginal epithelial tissue \\
& * Reduced expression of aquaporin proteins \\
& * Insufficient vaginal lubrication \\
& $*$ Reduced production of prostatic and seminal fluid \\
\hline Chronic, Systemic Inflammation & * Damage of penile and clitoral blood vessels \\
& * Reduced expression of nitric oxide (NO) \\
& * Increased expression of pro-contractile molecules \\
& * Reduced blood flow to genital tissues \\
\hline
\end{tabular}

\section{Obesity, Social Stereotypes, and Body Image Dissatisfaction}

Although medical research has traditionally evaluated obesity as an individual-level phenomenon, social scientists have long acknowledged that interpersonal, cultural, and institutional factors can contribute to body weight perception and weight management. In some cases, longstanding cultural values may also reflect evolutionary pressures to retain energy reserves when food scarcity is common [78]. For example, overweight/obesity in many low- and middle-income countries is associated with higher income, greater levels of educational attainment, and some degree of social status $[79,80]$. While not a universal trend, as many countries become more economically prosperous, obesity prevalence tends to increase within the poorer/economically deprived segments of the population rather than more affluent subgroups $[81,82]$. These trends have been attributed to a variety of factors such the relative affordability of energy-dense, nutrient-poor foods. In addition to individual-level food consumption and physical activity measurements, the odds of falling into an overweight/obese weight class can be modeled using neighborhood-level data, such as living within a food desert [83].

A person's experience of obesity may also be profoundly influenced by prevailing social norms and weight-related stigma. While both women and men have expressed body weight- and shape-related concerns in qualitative studies, there are significant differences regarding their perceptions of social stigma. For example, a purposeful sample of overweight/obese, limited-income white women $(n=25)$ revealed that the majority of 
respondents perceived their weight as less attractive to potential male partners, and many women experienced disparaging comments from family members, friends, romantic partners, and strangers [84]. Some participants reported workplace discrimination in the hiring process, and others indicated that clothing stores did not provide fashionable options in larger sizes. Despite a general desire to lose weight ( $48 \%$ wanting to become slightly thinner, $52 \%$ wanting to become much thinner), respondents simultaneously reported that excess body weight could prove advantageous during adverse circumstances such as financial hardship or displacement [84]. Weight stigma may also be compounded by discrimination due to other sociodemographic characteristics; an ecological momentary assessment (EMA) of 55 sexual minority women revealed that a striking percentage of weight stigma events also involved sexual orientation (43\%), gender $(25 \%)$, or race $(20 \%)$ [85].

Changes in weight perception have also been documented throughout the process of bariatric surgery. During their interviews with young women who had undergone bariatric surgery ( $n=5$, ages 20-25), Jensen and colleagues observed similar themes of social ridicule and body image dissatisfaction among the respondents prior to surgery [86]. Many participants described bariatric surgery as a strategy to increase control over their bodies, becoming more attentive to satiety signals and emotional triggers following the operation. Women also attributed increased social confidence and reduced marginalization within relationships to their weight loss [86]. Benefits to body image were also reported by Song et al. (2016), who evaluated pre- and postoperative bariatric surgery patients $(n=175)$ using the Multidimensional Body-Self Relations Questionnaire (MBSRQ) [87]. Multiple outcomes were statistically significant, including average scores for appearance evaluation and body area satisfaction. Interestingly, weight preoccupation levels did not decrease following the weight loss operation [87]. However, several patients did not complete questionnaires at the 6-, 12-, and 24-month follow-up sessions, and so these data must be interpreted with caution. Moreover, as Jumbe and colleagues duly note, most studies evaluate body image improvements over the short term (e.g., 6-12 months), when weight loss is most striking; more longitudinal studies are required to determine whether (and for how long) these body image improvements persist for bariatric surgery patients, particularly if weight regain occurs [88].

In contrast to these promising results, other studies have suggested that surgically mediated weight loss may not improve body image/shape concerns. In a retrospective survey of bariatric surgery patients ( $n=152,77 \%$ female), nearly $20 \%$ of respondents who expressed interest in a postoperative support group reported that they were not happy with their current appearance [89]. These respondents also indicated challenges maintaining their weight loss over the long-term [89]. Postoperative body image also appears to be related to excess skin (ptosis) which often occurs during rapid weight loss. Biörserud and colleagues (2018) evaluated self image, quality of life, and excess skin measurements in 131 adults (73\% female) who had received bariatric surgery between 2009-2012 [90]. Compared to men, women who underwent bariatric surgery had significantly greater arm ptosis, thigh ptosis, and overall ptosis (composite of abdomen, arm, and thigh measurements) postoperatively [90]. In a second set of analyses, participants were grouped by their level of discomfort from excess skin (operationalized as scores $\leq 4 \mathrm{vs.} \geq 5$ ), assessed by the Sahlgrenska Excess Skin Questionnaire (SESQ). Participants in the high distress/discomfort group reported significantly lower physical well-being $(p<0.0001)$ and lower relationship closeness $(p=0.014)$ compared to their more comfortable counterparts [90]. As an additional caveat, Masheb and colleagues [91] observed significant differences between body overevaluation and body image dissatisfaction, with only changes to the latter construct reducing negative affect in postoperative bariatric patients ( $n=145,89 \%$ female) [91]. While reductions in body overevaluation were associated with greater self-esteem, they had no impact on negative affect [91]. Thus, the investigators suggest that body overevaluation may be a more reliable construct for body image assessment, as it is not susceptible to changes in affect/mood [91]. 
Although women on average tend to report higher body dissatisfaction relative to men [92], traditional instruments have focused specifically on thinness as the socialized ideal body shape, a construct which is less applicable to men [93]. Thus, more recent body image research conducted with male participants has emphasized muscularity and the "mesomorphic ideal" [93]. For example, assessing both (dis)satisfaction with current muscularity and body fatness among men in the United States, Ukraine, and Ghana, Frederick and colleagues (2007) observed a consistent drive for greater muscularity across all three nations [94]. However, the investigators noted greater variation regarding body fatness for the US men; while most participants were either pleased with their current body fat level or desired to reduce body fat, a small minority of men who perceived themselves as thinner than average desired to accrue more body fat [94]. A convenience sample of undergraduate men $(n=25)$ revealed similar adherence to the muscular ideal in respondent narratives, with many men altering their dietary or physical activity behaviors to maintain a socially desirable physique [95]. Interestingly, a recent study by Tylka (2015) demonstrated negative effects of pornography on men's body image perception [96]. Respondents who endorsed watching pornography frequently exhibited greater internalization of the mesomorphic ideal, increased body monitoring/surveillance, greater fat- and muscularityrelated body dissatisfaction, and reduced body appreciation in the path analyses [96]. Taken together, these studies illustrate that men also face social pressures related to body size and shape, but their concerns may involve different body features/traits such as muscularity.

While weight-related stigma and discrimination elicit well-documented negative consequences for women and men, the relationship between overweight/obesity, body image, and mental health outcomes is equivocal. Using the 2012 Swiss Health Survey $(n=15,975)$, Richard and colleagues evaluated the impact of body weight dissatisfaction on depression via logistic regression [97]. After adjusting for sex, age, and other demographic covariates, the investigators found significantly greater odds of depression for individuals reporting body weight dissatisfaction compared to those satisfied with their current body weight. Interestingly, however, this significant relationship was observed at all BMI classification levels (underweight, normal weight, overweight, obese), and BMI did not serve as an effect modifier in the regression model [97]. An Australian sample of 1670 adolescent students (68\% female) showed a similar pattern, where the impact of obesity on psychological/emotional distress was mediated through body dissatisfaction, operationalized using the Weight/Shape Concerns Subscale of the Eating Disorder Examination Questionnaire (EDE-Q) [98]. The direct effect of obesity on psychological distress was not statistically significant, suggesting that excess body weight may have adverse mental health implications only when it impinges upon body image satisfaction/appraisal [98].

Recent studies have also suggested that internalization of weight-based stigma/social expectations can inhibit health behaviors that contribute to successful weight loss. For example, a survey of overweight/obese adults regularly attending a gym/fitness center revealed that experiences of weight stigma were associated with maladaptive coping strategies, including rapid weight loss (e.g., using diet pills or saunas) and emotional eating behaviors, as well as greater dissatisfaction with one's body [99]. Both weight stigma and internalized weight bias are associated with maladaptive eating patterns, including binge eating events, irrespective of participants' current BMIs [100]. Even more troubling, exposure to weight discrimination was associated with significantly higher odds of transitioning from an overweight to obese BMI classification [100]. As a result, some researchers have recommended behavioral interventions that prioritize health and psychosocial well-being without a strong emphasis on body weight or adiposity [101]. According to this view, positive, incremental changes that promote body appreciation may be more efficacious and produce longer-lasting effects [101,102]. Table 4 provides a summary of factors that contribute to body image appraisal and related psychosocial/mental health outcomes. 
Table 4. Factors related to body image appraisal and their psychosocial effects.

\begin{tabular}{|c|c|}
\hline Factors Influencing Body Image & Effects on Psychosocial Well-Being \\
\hline Weight Stigma & $\begin{array}{l}\text { * May include workplace discrimination and disparaging comments [84] } \\
\text { * Discrimination for weight can intersect with marginalized identities [85] } \\
\text { * Some women viewed excess weight as helpful during financial hardship [84] } \\
\text { * Stigma at the gym associated with unhealthy/rapid weight loss methods [99] } \\
\text { * Stigma increases maladaptive/binge eating and odds of weight gain }[99,100]\end{array}$ \\
\hline Body Weight and Depression & $\begin{array}{l}\text { * Body dissatisfaction predicts depression for all weight categories }[97,98] \\
\text { * Weight not significant predictor when body dissatisfaction controlled }[97,98]\end{array}$ \\
\hline Bariatric Surgery & $\begin{array}{l}\text { * Some patients show improved body confidence after surgery [86,87] } \\
\text { * Body weight preoccupation may not improve with weight loss [87] } \\
\text { * Suboptimal outcomes may be attributable to excess skin (ptosis) [90] } \\
\text { * Limitation: Longitudinal data are often not available beyond 6-12 months [88] }\end{array}$ \\
\hline Appearance Evaluation & $\begin{array}{l}\text { * Women experience pressures for thinness and stereotyped beauty }[84,86,91] \\
\text { * Weight loss can reduce need for external validation or fears of judgment [86] } \\
\text { * Men pressured to increase muscularity by diet and weight training [93-95] } \\
\text { * For men, pornography use increases stereotyped body image ideals/goals [96] }\end{array}$ \\
\hline
\end{tabular}

\section{The Human Sexual Response Cycle}

In the late 1960s, Masters and Johnson published Human Sexual Response, derived from laboratory observations of men and women during sexual intercourse [103]. Based upon the recorded physiologic changes during partnered sex, the investigators proposed a four-stage model of human sexual response. These stages-excitement, plateau, orgasm, resolution-were conceptually understood as "distinct and sequential" [104] (p. 2). Just over a decade later, Kaplan (1979) modified the initial framework to incorporate desire as a distinct psychosocial construct [105]. Kaplan further contended that many "nonresponders" to sex therapy were coping with low sexual desire, whereas conventional psychotherapies emphasized genital functioning and performance anxiety, features of the arousal phase [106]. Despite the intuitive appeal of a linear model, several researchers have also criticized the Masters-Johnson framework as too reductive, since it focuses primarily on physiologic changes during sexual intercourse to the exclusion of cognitive, emotional, and relationship factors.

Over recent decades, alternative models of human sexual response have been articulated to better account for the diverse sexual experiences of women and men. For example, the assumption that "spontaneous" sexual desire generally precedes genital arousal has been challenged by Basson and other clinicians, who assert that the desire for partnered sexual activity may arise as a response to ongoing stimulation or relational intimacy [107-109], particularly for women. These findings motivated Basson to propose a circular model of sexual response, where psychosocial and relationship inputs can increase a person's desire for/interest in sexual activity at any point within the cycle [107]. Similarly, the dual control model of sexual response evaluates a person's willingness and ability to engage in partnered sex as a balance between separate neurophysiologic systems of sexual excitation and inhibition, respectively $[110,111]$. In this model, sexual problems can be caused by either decreased sexual interest (i.e., low excitation) or higher levels of sexual inhibition [112,113]. Thus, both models of sexual response portray sexual activity as a dynamic behavior that is modified by environmental cues and relationship factors, rather than a linear response dictated entirely by physiologic processes.

Recent survey-based studies have also provided empirical evidence against a strictly linear model of sexual response. Recruiting a sample of 520 men through Amazon Mechanical Turk (MTurk), Busby and colleagues asked respondents to recall levels of sexual desire and arousal at seven time points during their most recent sexual encounter [114]. Using latent class modeling, the investigators found five empirically distinct patterns of desire and arousal for participants, including subgroups with consistently high desire/arousal, those with steep declines near the point of orgasm, and men whose level of desire/arousal fluctuated significantly throughout the sexual experience [114]. A second MTurk sample of 
women $(n=769)$ revealed similar patterns, with subgroups demonstrating high fluctuation, consistently low desire/arousal, and consistently high or moderately high desire/arousal during partnered sex [115]. Collectively, these studies challenge the assumption that desire and arousal necessarily proceed in an escalating, incremental fashion until the point of orgasm.

To fully appreciate the impact of obesity on body image appraisal and sexual functioning, we must consider the complex interactions between pathophysiology, deeply held beliefs or expectations regarding sexual performance, and socially derived values pertaining to sexuality and sexual roles. While a comprehensive treatment of these features is beyond the scope of this review, it attempts to capture their importance using a biopsychosocial model of sexual response. Within a biopsychosocial framework, health conditions can be addressed not only by their medical implications, but also by their impact on psychological well-being and social relations [116]. This model is particularly important for sexual problems, where an individual or couple's cultural background may strongly influence their appraisal/description of any sexual dysfunction and can encourage the attending physician or psychologist to provide a socially/culturally appropriate method of treatment [117].

\section{The Interplay of Obesity, Body Image Dissatisfaction, and Sexual Functioning}

The vast majority of studies relating obesity to body image and sexual function have been conducted using clinical samples of obese adults who often qualify for bariatric procedures. For example, evaluating a sample of eligible obese adults ( $n=53,83 \%$ female), Çaynak et al. observed a significant effect of body perception on sexual functioning, with higher body appraisal predicting greater sexual functioning in the linear regression model $\left(\mathrm{R}^{2}=7.4 \%\right)$ [118]. Similarly, in a qualitative study of childless women 18 months after bariatric surgery $(n=11)$, most respondents indicated that they were less concerned with the appraisal/judgment of other people, giving them greater confidence in social situations [119]. However, several participants indicated a desire for continuous bodily improvement, either through increased physical fitness or cosmetic surgical procedures. The impact of surgery on sexuality was difficult to interpret, as some participants reported greater sexual functioning (e.g., increased vaginal lubrication), whereas others indicated low sexual desire [119]. Kinzl et al. compared sexual measures in a pre-post design, noting that the majority of patients $(63 \%)$ experienced greater enjoyment of partnered sex 1 year following surgery, but only $20 \%$ suggested that relationship quality improved after the operation [120]. Although the investigators describe body image satisfaction as an important element of relationship quality, they did not report the construct as a separate outcome [120].

The severity of obesity may also be relevant, as individuals who were classified into the highest category of obesity (BMI $\geq 40 \mathrm{~kg} / \mathrm{m}^{2}$ ) reported less enjoyment of sexual activity, more sexual performance difficulties, and greater avoidance of sexual encounters than members of class I or class II obesity [121]. A study of young Italian women revealed similar findings, with obese respondents scoring significantly higher for depression and lower on the McCoy Female Sexuality Questionnaire [122]. Obese participants tended to engage in partnered sex less frequently than their lean counterparts, and they were more likely to experience anorgasmia. The obese respondents also tended to endorse larger silhouettes (per the Stunkard Figure Scale) as their ideal body type, which would still fall within the overweight/obese category. The investigators concluded that body image distortion may accompany obesity and influence weight loss expectations [122]. Unfortunately, few studies have been conducted examining obesity, body image, and sexual function using nonclinical and/or more representative samples (i.e., not relying on undergraduate students).

\section{Alternative Perspectives on Obesity: Body Positivity and Size Acceptance}

While research in the obesity field has traditionally emphasized adverse consequences of excess body weight, more recent efforts have assessed prejudicial attitudes toward 
overweight and obese persons. Several social beliefs have been postulated as contributors to weight-based stigma, including notions that obesity is an individual-level problem, unrelated to an obesogenic environment or genetic factors; that weight is entirely under voluntary control; and that people who are overweight or obese simply lack the motivation/willpower to lose weight or maintain a lower body weight [123]. Even more troubling, these disparaging attitudes are often unconsciously held and can be fortified or perpetuated by social institutions including healthcare and psychological services [123]. Qualitative studies have also revealed lower social support for overweight/obese women and men, with many respondents connecting with one another through online forums [124,125]. To address these challenges, body-positive social movements have promoted constructs such as body appreciation, self-compassion, and healthful behaviors that can be successfully implemented without concomitant weight loss [126]. For example, Health at Every Size (HAES) campaigns have been described as follows: "All people deserve to be treated with dignity and respect, and provided with fair access to opportunities and environmental conditions that enhance their health and wellbeing, irrespective of their body weight" [126] (p. 226). Importantly, attitudes toward obesity tend to exist on a spectrum and remain controversial. Some professionals perceive weight loss as the most important attribute of healthcare for overweight/obese patients, whereas others describe weight loss as a desirable outcome while still promoting body image and self-esteem improvements as foundational goals of medical care for this population [127]. In contrast, some proponents of body positivity/fat acceptance insist that any intentional weight loss is problematic, as it promotes fatphobic societal attitudes. Others hold more moderate positions in which one's body should be celebrated or valued as it is, but individuals may choose to lose (or gain) weight if they are so inclined [127]. One criticism of body positivity movements is their underdeveloped public health applications; while HAES offers effective strategies to improve self-esteem and mindful eating (recognizing internal hunger cues, etc.) within individuals, its coverage of obesogenic social determinants is limited [128].

HAES-related interventions are not yet abundant in the research literature, but several recent findings suggest that a body-positive approach may promote psychosocial and physical health outcomes. For example, Sabatini and colleagues randomized a sample of obese women ( $n=43$, ages 25-50) to receive either a combination treatment of nutritional counseling, HAES workshops, and group physical activity, or informational HAES lectures only (control group) [129]. At baseline and after the 7-month intervention period, the women participated in qualitative interviews regarding eating habits, perceived control, and pleasure from food consumption. In comparison to the control group, women in the HAES intervention reported greater autonomy/decision making over food choices, experienced more guiltless eating (i.e., acknowledging pleasure during eating occasions) and reduced emotional eating, as well as a greater desire to prepare one's own meals after the intervention [129]. A similar study compared a HAES intervention to a comparable social support group and waiting-list controls $(n=144$ women, with 48 women randomized to each group) [130]. Compared to the control group, both the HAES and social support interventions resulted in significantly lower susceptibility to hunger and situational disinhibition (i.e., overeating due to situational factors) [130].

Other treatment modalities have incorporated acceptance-based therapies (ABT) that transcend traditional behavioral messaging (e.g., choosing more healthful foods, increasing physical activity, etc.). For example, Forman et al. randomized a sample of overweight and obese participants $\left(n=190\right.$, BMI range $\left.=27-50 \mathrm{~kg} / \mathrm{m}^{2}\right)$ to receive either ABT or the behavioral standard-of-care for a 12-month period [131]. Patients in the ABT group exhibited significantly greater weight loss at 12 months, as well as an enhanced ability to maintain weight loss compared to controls. Importantly, these beneficial effects were mediated by greater acceptance of food cravings/discomfort and a higher level of autonomous motivation [131]. Likewise, Berman et al. (2016) pilot tested an integrated HAES/ Acceptance and Commitment Therapy (HAES-ACT) program among depressed, obese women ( $n=10-12$ per group) [132]. The majority of respondents perceived the 
mindfulness training, self-acceptance (i.e., acknowledging rather than suppressing negative thoughts or emotions), and supportive social environment as helpful components of the intervention [132].

Although relatively few studies measure body image satisfaction, obesity, and sexual functioning concomitantly, recent findings have offered several promising avenues for continued research. For example, Yilmaz and colleagues assessed the relationship between body image and sexual quality of life in women across weight classifications [133]. In their analyses, higher scores on the Body Image Scale (BIS) were positively associated with Sexual Quality of Life (SQL-W) measures, and this relationship was observed for women in the healthy, overweight, and obese weight categories. Moreover, a linear regression model revealed that the BIS value was a significant predictor for SQL-W $(\beta=0.38, \mathrm{SE}=0.02, p<0.001)$, and the model explained approximately $15 \%$ of variance in women's SQL-W scores. Taken together, these data indicate that body image satisfaction is strongly tied to women's sexual experiences, and more positive appraisals of their bodies may increase sexual responsivity [133]. Taking a different approach, Parchomiuk and Kirenko (2021) evaluated sexual satisfaction in healthy weight and obese respondents, using their self-reported interest in and frequencies of partnered sexual behaviors (i.e., foreplay, oral-manual stimulation, partner's activity/role during intercourse, mutual activity, and fulfilling new fantasies/positions) [134]. For the obese respondents, discrepancies between the desired and actual frequencies of foreplay activities as well as the partner's activity during intercourse significantly impacted sexual satisfaction. These findings suggest that sexual satisfaction can be readily improved for obese women and men by attending to those activities which are more pleasurable or desirable for them [134]. Sexual pleasure may also be enhanced by an internalized sense of attractiveness or value; a qualitative sample of undergraduate women $(n=4)$ showed that respondents who did not seek external validation for their appearance/sexual desirability tended to report more fulfilling sexual relationships and greater body confidence [135]. Table 5 summarizes these associations between body image, body positivity, obesity, and sexual functioning.

Table 5. Intersection of overweight/obesity, body image/positivity constructs, and sexuality.

\section{Research Findings}

* Health at Every Size (HAES) programs improve mindfulness while eating [129,132]

* HAES modalities reduce emotional eating and increase guiltless eating [129-131]

* Body satisfaction predicts higher sexual quality of life for all weight classes [133]

* Sexual satisfaction for obese women/men affected by sex behavior discrepancies [134]

* Sexual pleasure higher for overweight women with internalized body confidence [135]

* Weight loss may increase sex frequency/pleasure, but results are inconsistent $[119,120]$

* Negative obesity effects on sexual function more likely for highest obese classes [121]

\section{Discussion and Conclusions}

\subsection{Interpretation of Results}

Continued research advances have demonstrated wide-ranging effects of obesity on the sexual response, both through physiological changes and psychosocial factors. Based on the current biomedical data, defects in adipocyte functioning, chronic hyperglycemia, disruption of androgen-estrogen ratios, and low-grade systemic inflammation represent the most promising mechanisms for further research. Sexual medicine is well poised to address these complications in collaboration with other physician specialties. In addition to these medical advances, several research findings have demonstrated that obesity can influence body image appraisal and (dis)satisfaction, as well as mental health outcomes. Importantly, however, these relationships do not appear to be unidirectional: more favorable body image appraisal could protect against adverse mental health outcomes that have been traditionally attributed to excess body weight. Even more promising, body appreciation may improve individuals' adherence to healthful dietary patterns, irrespective of their current body weight/adiposity. 
Although the available data also suggest an association between body image appraisal and sexual functioning, this relationship has been infrequently evaluated for women and men with overweight/obesity. Ideally, ongoing research will more consistently assess obesity, body image constructs, and sexual functioning/sexual satisfaction within the same participants. Longitudinal datasets will help to determine whether trends in sexual function or body image dissatisfaction mirror increases or decreases in BMI [136]. Currently, studies evaluating these constructs in tandem tend to recruit clinical samples in which body image and sexual functioning are evaluated following bariatric surgery or inpatient weight loss programs [137]. While these pre-post interventions are highly informative, there is also some evidence that individuals seeking bariatric surgery have greater body image concerns or health complications than their obese counterparts who do not elect to undergo these surgical procedures [121]. Thus, the generalizability of such findings is unclear.

\subsection{Limitations}

Despite the rich conceptual/theoretical frameworks proposed by body image researchers, such as objectification theory, few biomedical studies have incorporated these constructs. While objectification theory has been addressed by feminist scholars and psychologists alike [138], the extent to which the framework has been applied to sexual functioning more specifically is limited [139,140]. Moreover, current studies typically address body image (dis)satisfaction from either the individual's perspective or prevailing social norms. It is less understood, in contrast, how weight stigma functions within sexual relationships, where disparaging comments or attitudes from an unsupportive partner might exacerbate pre-existing sexual problems or reduce sexual engagement [141]. Additionally, due to the comparative lack of longitudinal data, the process by which women and men internalize body stereotypes that negatively impact their sexual functioning is understudied [140]. Finally, constructs such as body image dis(satisfaction) or appreciation have primarily been assessed in convenience samples and smaller-scale quantitative designs. Future work incorporating probability-based sampling designs will better characterize the prevalence of body image concerns among the general population.

\subsection{Implications for Future Research and Practice}

Taken together, the findings reported here can help identify areas where additional research is warranted. Currently, evidence for the interrelationships between obesity, body image, and sexual function tends to be indirect, with the effects of obesity on sexual function characterized separately from its influence on body image constructs. As an additional challenge, body image evaluation/appraisal and satisfaction have been typically assessed as outcomes rather than as independent variables/predictors. This practice has limited our ability to consider body image dissatisfaction as a mediating variable between obesity and sexual dysfunction. Lastly, biomedical and psychological research has often considered the adverse effects of obesity on physical and mental health outcomes, with minimal attention to possible sexual pleasure or fantasy. The recent body positivity literature has suggested that more affirming/self-compassionate body image appraisal may protect against some threats to sexual pleasure or satisfaction. Ideally, these relationships will continue to be explored as body image constructs receive greater transdisciplinary attention. Due to the well-established association between body image and sexual functioning, healthcare professionals might also consider body image appraisal as a critical feature of sexual health and well-being for all weight classes.

Funding: This research received no external funding.

Institutional Review Board Statement: Not applicable.

Informed Consent Statement: Not applicable.

Data Availability Statement: Data sharing not applicable: This review did not report any original data. 
Acknowledgments: I am grateful to the reviewers who carefully evaluated the manuscript and provided detailed feedback to improve its quality.

Conflicts of Interest: The author declares no conflict of interest.

\section{Appendix A}

The following table (Table A1) lists the primary topics of the review and provides the number and organization of references for each section.

Table A1. Parenthetical citations for each of the manuscript sections.

\begin{tabular}{lcc}
\hline \multicolumn{1}{c}{ Section/Topic in Manuscript } & References Cited & Number of References \\
\hline $\begin{array}{l}\text { Introduction: Prevalence, Economic, } \\
\text { and Health Consequences of Obesity }\end{array}$ & {$[1-20]$} & $n=20$ \\
\hline Methods of the Literature Review & {$[21-23]$} & $n=3$ \\
\hline $\begin{array}{l}\text { Pathophysiological Mechanisms of } \\
\text { Obesity and Lifestyle Interventions }\end{array}$ & {$[24-59]$} & $n=36$ \\
\hline Obesity and Sexual Dysfunction & {$[24,29,60-77]$} & $n=20$ \\
\hline $\begin{array}{l}\text { Obesity, Social Stigma, Body Image, } \\
\text { and Bariatric Surgery }\end{array}$ & {$[78-102]$} & $n=25$ \\
\hline The Human Sexual Response Cycle & {$[103-117]$} & $n=15$ \\
\hline $\begin{array}{l}\text { Interplay of Obesity, Body Image, and } \\
\text { Sexual Dysfunction }\end{array}$ & {$[118-122]$} & $n=5$ \\
\hline Body Positivity and Size Acceptance & {$[123-135]$} & $n=13$ \\
\hline Discussion and Conclusions & {$[121,136-141]$} & $n=7$ \\
\hline
\end{tabular}

\section{References}

1. Hales, C.M.; Fryar, C.D.; Carroll, M.D.; Freedman, D.S.; Ogden, C.L. Trends in Obesity and Severe Obesity Prevalence in US Youth and Adults by Sex and Age, 2007-2008 to 2015-2016. JAMA 2018, 319, 1723-1725. [CrossRef] [PubMed]

2. Hales, C.M.; Carroll, M.D.; Fryar, C.D.; Ogden, C.L. Prevalence of Obesity and Severe Obesity Among Adults: United States, 2017-2018. NCHS Data Brief 2020, 360, 1-8.

3. Fryar, C.D.; Carroll, M.D.; Afful, J. Prevalence of Overweight, Obesity, and Severe Obesity among Adults Aged 20 and over: United States, 1960-1962 through 2017-2018. National Center for Health Statistics, 2020. Available online: https://www.cdc.gov / nchs/data/hestat/obesity-adult-17-18/overweight-obesity-adults-H.pdf (accessed on 5 January 2022).

4. $\quad$ Finkelstein, E.A.; Khavjou, O.A.; Thompson, H.; Trogdon, J.G.; Pan, L.; Sherry, B.; Dietz, W. Obesity and Severe Obesity Forecasts Through 2030. Am. J. Prev. Med. 2012, 42, 563-570. [CrossRef] [PubMed]

5. Chooi, Y.C.; Ding, C.; Magkos, F. The epidemiology of obesity. Metabolism 2019, 92, 6-10. [CrossRef]

6. Withrow, D.; Alter, D.A. The economic burden of obesity worldwide: A systematic review of the direct costs of obesity. Obes. Rev. 2011, 12, 131-141. [CrossRef]

7. Min, J.; Zhao, Y.; Slivka, L.; Wang, Y. Double burden of diseases worldwide: Coexistence of undernutrition and overnutritionrelated non-communicable chronic diseases. Obes. Rev. 2018, 19, 49-61. [CrossRef]

8. Drewnowski, A. Obesity, diets, and social inequalities. Nutr. Rev. 2009, 67 (Suppl. 1), S36-S39. [CrossRef]

9. Ogden, C.L.; Fryar, C.D.; Hales, C.M.; Carroll, M.D.; Aoki, Y.; Freedman, D.S. Differences in Obesity Prevalence by Demographics and Urbanization in US Children and Adolescents, 2013-2016. JAMA 2018, 319, 2410-2418. [CrossRef]

10. Janssen, I.; Katzmarzyk, P.T.; Boyce, W.F.; Vereecken, C.; Mulvihill, C.; Roberts, C.; Currie, C.; Pickett, W. Comparison of overweight and obesity prevalence in school-aged youth from 34 countries and their relationships with physical activity and dietary patterns. Obes. Rev. 2005, 6, 123-132. [CrossRef]

11. Singh, A.S.; Mulder, C.; Twisk, J.W.; van Mechelen, W.; Chinapaw, M.J. Tracking of childhood overweight into adulthood: A systematic review of the literature. Obes. Rev. 2008, 9, 474-488. [CrossRef]

12. Linder, B.L.; Fradkin, J.E.; Rodgers, G.P. The TODAY Study: An NIH Perspective on Its Implications for Research. Diabetes Care 2013, 36, 1775. [CrossRef] [PubMed]

13. TODAY Study Group. Effects of Metformin, Metformin Plus Rosiglitazone, and Metformin Plus Lifestyle on Insulin Sensitivity and $\beta$-Cell Function in TODAY. Diabetes Care 2013, 36, 1749. [CrossRef]

14. Esfahani, S.B.; Pal, S. Does Metabolic Syndrome Impair Sexual Functioning in Adults With Overweight and Obesity? Int. J. Sex. Health 2019, 31, 170-185. [CrossRef] 
15. Kim, D.; Hou, W.; Wang, F.; Arcan, C. Factors Affecting Obesity and Waist Circumference Among US Adults. Prev. Chronic Dis. 2019, 16, E02. [CrossRef] [PubMed]

16. Abdullah, A.; Peeters, A.; de Courten, M.; Stoelwinder, J. The magnitude of association between overweight and obesity and the risk of diabetes: A meta-analysis of prospective cohort studies. Diabetes Res. Clin. Pract. 2010, 89, 309-319. [CrossRef] [PubMed]

17. Patel, S.A.; Deepa, M.; Shivashankar, R.; Ali, M.K.; Kapoor, D.; Gupta, R.; Lall, D.; Tandon, N.; Mohan, V.; Kadir, M.M.; et al. Comparison of multiple obesity indices for cardiovascular disease risk classification in South Asian adults: The CARRS Study. PLoS ONE 2017, 12, e0174251. [CrossRef]

18. Maiorino, M.I.; Bellastella, G.; Giugliano, D.; Esposito, K. From inflammation to sexual dysfunctions: A journey through diabetes, obesity, and metabolic syndrome. J. Endocrinol. Investig. 2018, 41, 1249-1258. [CrossRef]

19. Esposito, K.; Giugliano, F.; Ciotola, M.; De Sio, M.; D'Armiento, M.; Giugliano, D. Obesity and sexual dysfunction, male and female. Int. J. Impot. Res. 2008, 20, 358-365. [CrossRef]

20. Larsen, S.H.; Wagner, G.; Heitmann, B.L. Sexual function and obesity. Int. J. Obes. 2007, 31, 1189-1198. [CrossRef]

21. Rosen, R.; Brown, C.; Heiman, J.; Leiblum, S.; Meston, C.; Shabsigh, R.; Ferguson, D.; D'Agostino, R., Jr. The Female Sexual Function Index (FSFI): A multidimensional self-report instrument for the assessment of female sexual function. J. Sex Marital Ther. 2000, 26, 191-208. [CrossRef] [PubMed]

22. Wiegel, M.; Meston, C.; Rosen, R. The female sexual function index (FSFI): Cross-validation and development of clinical cutoff scores. J. Sex Marital Ther. 2005, 31, 1-20. [CrossRef]

23. Rosen, R.C.; Riley, A.; Wagner, G.; Osterloh, I.H.; Kirkpatrick, J.; Mishra, A. The international index of erectile function (IIEF): A multidimensional scale for assessment of erectile dysfunction. Urology 1997, 49, 822-830. [CrossRef]

24. Rowland, D.L.; McNabney, S.M.; Mann, A.R. Sexual Function, Obesity, and Weight Loss in Men and Women. Sex. Med. Rev. 2017, 5, 323-338. [CrossRef] [PubMed]

25. Harvey, I.; Boudreau, A.; Stephens, J.M. Adipose tissue in health and disease. Open Biol. 2020, 10, 200291. [CrossRef] [PubMed]

26. Da Silva Rosa, S.C.; Nayak, N.; Caymo, A.M.; Gordon, J.W. Mechanisms of muscle insulin resistance and the cross-talk with liver and adipose tissue. Physiol. Rep. 2020, 8, e14607. [CrossRef] [PubMed]

27. Petersen, M.C.; Shulman, G.I. Mechanisms of Insulin Action and Insulin Resistance. Physiol. Rev. 2018, 98, 2133-2223. [CrossRef] [PubMed]

28. Samuel, V.T.; Shulman, G.I. The pathogenesis of insulin resistance: Integrating signaling pathways and substrate flux. J. Clin. Investig. 2016, 126, 12-22. [CrossRef] [PubMed]

29. Frayn, K.N. Metabolic Regulation: A Human Perspective, 3rd ed.; Wiley-Blackwell: Malden, MA, USA, 2010.

30. Coen, P.M.; Goodpaster, B.H. Role of intramyocelluar lipids in human health. Trends Endocrinol. Metab. 2012, 23, 391-398. [CrossRef]

31. Goodpaster, B.H.; Sparks, L.M. Metabolic Flexibility in Health and Disease. Cell Metab. 2017, 25, 1027-1036. [CrossRef]

32. Muoio, D.M. Metabolic inflexibility: When mitochondrial indecision leads to metabolic gridlock. Cell 2014, 159, 1253-1262. [CrossRef]

33. Sangwung, P.; Petersen, K.F.; Shulman, G.I.; Knowles, J.W. Mitochondrial Dysfunction, Insulin Resistance, and Potential Genetic Implications. Endocrinology 2020, 161, bqaa017. [CrossRef] [PubMed]

34. Bäck, M.; Yurdagul, A., Jr.; Tabas, I.; Öörni, K.; Kovanen, P.T. Inflammation and its resolution in atherosclerosis: Mediators and therapeutic opportunities. Nat. Rev. Cardiol. 2019, 16, 389-406. [CrossRef] [PubMed]

35. Netea, M.G.; Balkwill, F.; Chonchol, M.; Cominelli, F.; Donath, M.Y.; Giamarellos-Bourboulis, E.J.; Golenbock, D.; Gresnigt, M.S.; Heneka, M.T.; Hoffman, H.M.; et al. A guiding map for inflammation. Nat. Immunol. 2017, 18, 826-831. [CrossRef] [PubMed]

36. Poznyak, A.; Grechko, A.V.; Poggio, P.; Myasoedova, V.A.; Alfieri, V.; Orekhov, A.N. The Diabetes Mellitus-Atherosclerosis Connection: The Role of Lipid and Glucose Metabolism and Chronic Inflammation. Int. J. Mol. Sci. 2020, 21, 1835. [CrossRef]

37. Floyd, Z.E.; Stephens, J.M. Controlling a master switch of adipocyte development and insulin sensitivity: Covalent modifications of PPAR $\gamma$. Biochim. Biophys. Acta 2012, 1822, 1090-1095. [CrossRef]

38. Cao, Y. Adipose tissue angiogenesis as a therapeutic target for obesity and metabolic diseases. Nat. Rev. Drug Discov. 2010, 9 , 107-115. [CrossRef]

39. Murano, I.; Barbatelli, G.; Parisani, V.; Latini, C.; Muzzonigro, G.; Castellucci, M.; Cinti, S. Dead adipocytes, detected as crown-like structures, are prevalent in visceral fat depots of genetically obese mice. J. Lipid Res. 2008, 49, 1562-1568. [CrossRef]

40. Altintas, M.M.; Azad, A.; Nayer, B.; Contreras, G.; Zaias, J.; Faul, C.; Reiser, J.; Nayer, A. Mast cells, macrophages, and crown-like structures distinguish subcutaneous from visceral fat in mice. J. Lipid Res. 2011, 52, 480-488. [CrossRef]

41. Lin, D.; Chun, T.H.; Kang, L. Adipose extracellular matrix remodelling in obesity and insulin resistance. Biochem. Pharmacol. 2016, 119, 8-16. [CrossRef]

42. Kenđel Jovanović, G.; Mrakovcic-Sutic, I.; Pavičić Žeželj, S.; Šuša, B.; Rahelić, D.; Klobučar Majanović, S. The Efficacy of an Energy-Restricted Anti-Inflammatory Diet for the Management of Obesity in Younger Adults. Nutrients 2020, 12, 3583. [CrossRef]

43. Ruiz-Canela, M.; Zazpe, I.; Shivappa, N.; Hébert, J.R.; Sánchez-Tainta, A.; Corella, D.; Salas-Salvadó, J.; Fitó, M.; Lamuela-Raventós, R.M.; Rekondo, J.; et al. Dietary inflammatory index and anthropometric measures of obesity in a population sample at high cardiovascular risk from the PREDIMED (PREvención con DIeta MEDiterránea) trial. Br. J. Nutr. 2015, 113, 984-995. [CrossRef] 
44. Fuentes, G.C.; Castañer, O.; Warnberg, J.; Subirana, I.; Buil-Cosiales, P.; Salas-Salvadó, J.; Corella, D.; Serra-Majem, L.; Romaguera, D.; Estruch, R.; et al. Prospective association of physical activity and inflammatory biomarkers in older adults from the PREDIMED-Plus study with overweight or obesity and metabolic syndrome. Clin. Nutr. 2020, 39, 3092-3098. [CrossRef] [PubMed]

45. McLeod, A.; Schiffer, L.; Castellanos, K.; DeMott, A.; Olender, S.; Fitzgibbon, M.; Hughes, S.; Fantuzzi, G.; Tussing-Humphreys, L. Impact of Physical Activity and Weight Loss on Fat Mass, Glucose Metabolism, and Inflammation in Older African Americans with Osteoarthritis. Nutrients 2020, 12, 3299. [CrossRef] [PubMed]

46. Hasson, R.E.; Adam, T.C.; Davis, J.N.; Kelly, L.A.; Ventura, E.E.; Byrd-Williams, C.E.; Toledo-Corral, C.M.; Roberts, C.K.; Lane, C.J.; Azen, S.P.; et al. Randomized controlled trial to improve adiposity, inflammation, and insulin resistance in obese African-American and Latino youth. Obesity 2012, 20, 811-818. [CrossRef]

47. Lee, S.; Libman, I.; Hughan, K.; Kuk, J.L.; Jeong, J.H.; Zhang, D.; Arslanian, S. Effects of Exercise Modality on Insulin Resistance and Ectopic Fat in Adolescents with Overweight and Obesity: A Randomized Clinical Trial. J. Pediatr. 2019, 206, 91-98.e91. [CrossRef]

48. Freitas, W.R., Jr.; Oliveira, L.V.F.; Perez, E.A.; Ilias, E.J.; Lottenberg, C.P.; Silva, A.S.; Urbano, J.J.; Oliveira, M.C., Jr.; Vieira, R.P.; Ribeiro-Alves, M.; et al. Systemic Inflammation in Severe Obese Patients Undergoing Surgery for Obesity and Weight-Related Diseases. Obes. Surg. 2018, 28, 1931-1942. [CrossRef]

49. Devarshi, P.P.; McNabney, S.M.; Henagan, T.M. Skeletal Muscle Nucleo-Mitochondrial Crosstalk in Obesity and Type 2 Diabetes. Int. J. Mol. Sci. 2017, 18, 831. [CrossRef]

50. Koves, T.R.; Ussher, J.R.; Noland, R.C.; Slentz, D.; Mosedale, M.; Ilkayeva, O.; Bain, J.; Stevens, R.; Dyck, J.R.; Newgard, C.B.; et al Mitochondrial overload and incomplete fatty acid oxidation contribute to skeletal muscle insulin resistance. Cell Metab. 2008, 7, 45-56. [CrossRef] [PubMed]

51. Ruegsegger, G.N.; Creo, A.L.; Cortes, T.M.; Dasari, S.; Nair, K.S. Altered mitochondrial function in insulin-deficient and insulin-resistant states. J. Clin. Investig. 2018, 128, 3671-3681. [CrossRef]

52. Townsend, L.K.; Brunetta, H.S.; Mori, M.A.S. Mitochondria-associated ER membranes in glucose homeostasis and insulin resistance. Am. J. Physiol. Endocrinol. Metab. 2020, 319, E1053-E1060. [CrossRef]

53. Gao, Z.; Yin, J.; Zhang, J.; Ward, R.E.; Martin, R.J.; Lefevre, M.; Cefalu, W.T.; Ye, J. Butyrate Improves Insulin Sensitivity and Increases Energy Expenditure in Mice. Diabetes 2009, 58, 1509. [CrossRef] [PubMed]

54. Vidrine, K.; Ye, J.; Martin, R.J.; McCutcheon, K.L.; Raggio, A.M.; Pelkman, C.; Durham, H.A.; Zhou, J.; Senevirathne, R.N.; Williams, C.; et al. Resistant starch from high amylose maize (HAM-RS2) and dietary butyrate reduce abdominal fat by a different apparent mechanism. Obesity 2014, 22, 344-348. [CrossRef]

55. McNabney, S.M.; Henagan, T.M. Short Chain Fatty Acids in the Colon and Peripheral Tissues: A Focus on Butyrate, Colon Cancer Obesity and Insulin Resistance. Nutrients 2017, 9, 1348. [CrossRef]

56. Robertson, M.D.; Wright, J.W.; Loizon, E.; Debard, C.; Vidal, H.; Shojaee-Moradie, F.; Russell-Jones, D.; Umpleby, A.M. Insulinsensitizing effects on muscle and adipose tissue after dietary fiber intake in men and women with metabolic syndrome. J. Clin. Endocrinol. Metab. 2012, 97, 3326-3332. [CrossRef]

57. Mukaida, S.; Evans, B.A.; Bengtsson, T.; Hutchinson, D.S.; Sato, M. Adrenoceptors promote glucose uptake into adipocytes and muscle by an insulin-independent signaling pathway involving mechanistic target of rapamycin complex 2. Pharmacol. Res. 2017, 116, 87-92. [CrossRef] [PubMed]

58. Krishnapuram, R.; Kirk-Ballard, H.; Dhurandhar, E.J.; Dubuisson, O.; Messier, V.; Rabasa-Lhoret, R.; Hegde, V.; Aggarwal, S.; Dhurandhar, N.V. Insulin receptor-independent upregulation of cellular glucose uptake. Int. J. Obes. 2013, 37, 146-153. [CrossRef]

59. Di Meo, S.; Iossa, S.; Venditti, P. Improvement of obesity-linked skeletal muscle insulin resistance by strength and endurance training. J. Endocrinol. 2017, 234, R159-R181. [CrossRef] [PubMed]

60. Badoud, F.; Lam, K.P.; Perreault, M.; Zulyniak, M.A.; Britz-McKibbin, P.; Mutch, D.M. Metabolomics Reveals Metabolically Healthy and Unhealthy Obese Individuals Differ in their Response to a Caloric Challenge. PLoS ONE 2015, 10, e0134613. [CrossRef]

61. Mongraw-Chaffin, M.; Foster, M.C.; Kalyani, R.R.; Vaidya, D.; Burke, G.L.; Woodward, M.; Anderson, C.A.M. Obesity Severity and Duration Are Associated With Incident Metabolic Syndrome: Evidence Against Metabolically Healthy Obesity From the Multi-Ethnic Study of Atherosclerosis. J. Clin. Endocrinol. Metab. 2016, 101, 4117-4124. [CrossRef]

62. Torres, J.M.; Cox, N.J.; Philipson, L.H. Genome wide association studies for diabetes: Perspective on results and challenges. Pediatr. Diabetes 2013, 14, 90-96. [CrossRef] [PubMed]

63. Kronenberg, F. Genome-wide association studies in aging-related processes such as diabetes mellitus, atherosclerosis and cancer. Exp. Gerontol. 2008, 43, 39-43. [CrossRef]

64. Langenberg, C.; Lotta, L.A. Genomic insights into the causes of type 2 diabetes. Lancet 2018, 391, 2463-2474. [CrossRef]

65. Zahid, H.; Simpson, E.R.; Brown, K.A. Inflammation, dysregulated metabolism and aromatase in obesity and breast cancer. Curr. Opin. Pharmacol. 2016, 31, 90-96. [CrossRef]

66. Bhardwaj, P.; Au, C.C.; Benito-Martin, A.; Ladumor, H.; Oshchepkova, S.; Moges, R.; Brown, K.A. Estrogens and breast cancer: Mechanisms involved in obesity-related development, growth and progression. J. Steroid Biochem. Mol. Biol. 2019, 189, 161-170. [CrossRef] [PubMed] 
67. Kim, S.O.; Lee, H.S.; Ahn, K.; Park, K. Effect of estrogen deprivation on the expression of aquaporins and nitric oxide synthases in rat vagina. J. Sex. Med. 2009, 6, 1579-1586. [CrossRef]

68. Benetti-Pinto, C.L.; Ferreira, S.R.; Antunes, A., Jr.; Yela, D.A. The influence of body weight on sexual function and quality of life in women with polycystic ovary syndrome. Arch. Gynecol. Obstet. 2015, 291, 451-455. [CrossRef] [PubMed]

69. Cushman, T.T.; Kim, N.; Hoyt, R.; Traish, A.M. Estradiol ameliorates diabetes-induced changes in vaginal structure of db/db mouse model. J. Sex. Med. 2009, 6, 2467-2479. [CrossRef]

70. Lee, H.S.; Li, Z.; Kim, S.O.; Ahn, K.; Kim, N.N.; Park, K. Effect of hyperglycemia on expression of aquaporins in the rat vagina Urology 2012, 80, 737.e7. [CrossRef]

71. Pei, L.; Jiang, J.; Jiang, R.; Ouyang, F.; Yang, H.; Cheng, Y.; Fan, Z. Expression of aquaporin proteins in vagina of diabetes mellitus rats. J. Sex. Med. 2013, 10, 342-349. [CrossRef]

72. Bijlsma-Rutte, A.; Braamse, A.M.J.; van Oppen, P.; Snoek, F.J.; Enzlin, P.; Leusink, P.; Nijpels, G.; Elders, P.J.M. Screening for sexual dissatisfaction among people with type 2 diabetes in primary care. J. Diabetes Complicat. 2017, 31, 1614-1619. [CrossRef]

73. Pei, L.; Yang, G.; Jiang, J.; Jiang, R.; Deng, Q.; Chen, B.; Gan, X. Expression of aquaporins in prostate and seminal vesicles of diabetic rats. J. Sex. Med. 2013, 10, 2975-2985. [CrossRef] [PubMed]

74. Corbin, J.D.; Francis, S.H. Cyclic GMP phosphodiesterase-5: Target of sildenafil. J. Biol. Chem. 1999, 274, 13729-13732. [CrossRef] [PubMed]

75. Allahdadi, K.J.; Hannan, J.L.; Tostes, R.C.; Webb, R.C. Endothelin-1 induces contraction of female rat internal pudendal and clitoral arteries through ET(A) receptor and rho-kinase activation. J. Sex. Med. 2010, 7, 2096-2103. [CrossRef] [PubMed]

76. Allahdadi, K.J.; Hannan, J.L.; Ergul, A.; Tostes, R.C.; Webb, R.C. Internal pudendal artery from type 2 diabetic female rats demonstrate elevated endothelin-1-mediated constriction. J. Sex. Med. 2011, 8, 2472-2483. [CrossRef]

77. Sánchez, A.; Martínez, P.; Muñoz, M.; Benedito, S.; García-Sacristán, A.; Hernández, M.; Prieto, D. Endothelin-1 contributes to endothelial dysfunction and enhanced vasoconstriction through augmented superoxide production in penile arteries from insulin-resistant obese rats: Role of ET(A) and ET(B) receptors. Br. J. Pharmacol. 2014, 171, 5682-5695. [CrossRef]

78. Frederick, D.A.; Reynolds, T.A. The Value of Integrating Evolutionary and Sociocultural Perspectives on Body Image. Arch. Sex. Behav. 2021, 1-10. [CrossRef]

79. Subramanian, S.V.; Perkins, J.M.; Khan, K.T. Do burdens of underweight and overweight coexist among lower socioeconomic groups in India? Am. J. Clin. Nutr. 2009, 90, 369-376. [CrossRef]

80. Neuman, M.; Finlay, J.E.; Davey Smith, G.; Subramanian, S.V. The poor stay thinner: Stable socioeconomic gradients in BMI among women in lower- and middle-income countries. Am. J. Clin. Nutr. 2011, 94, 1348-1357. [CrossRef]

81. Templin, T.; Cravo Oliveira Hashiguchi, T.; Thomson, B.; Dieleman, J.; Bendavid, E. The overweight and obesity transition from the wealthy to the poor in low- and middle-income countries: A survey of household data from 103 countries. PLoS Med. 2019, 16, e1002968. [CrossRef]

82. Jones-Smith, J.C.; Gordon-Larsen, P.; Siddiqi, A.; Popkin, B.M. Is the burden of overweight shifting to the poor across the globe? Time trends among women in 39 low- and middle-income countries (1991-2008). Int. J. Obes. 2012, 36, 1114-1120. [CrossRef]

83. Chen, D.; Jaenicke, E.C.; Volpe, R.J. Food Environments and Obesity: Household Diet Expenditure Versus Food Deserts. Am. J. Public Health 2016, 106, 881-888. [CrossRef]

84. Parker, S.; Keim, K.S. Emic perspectives of body weight in overweight and obese white women with limited income. J. Nutr. Educ. Behav. 2004, 36, 282-289. [CrossRef]

85. Panza, E.; Olson, K.; Goldstein, C.M.; Selby, E.A.; Lillis, J. Characterizing Lifetime and Daily Experiences of Weight Stigma among Sexual Minority Women with Overweight and Obesity: A Descriptive Study. Int. J. Environ. Res. Public Health 2020, 17, 4892. [CrossRef] [PubMed]

86. Jensen, J.F.; Petersen, M.H.; Larsen, T.B.; Jørgensen, D.G.; Grønbaek, H.N.; Midtgaard, J. Young adult women's experiences of body image after bariatric surgery: A descriptive phenomenological study. J. Adv. Nurs. 2014, 70, 1138-1149. [CrossRef]

87. Song, P.; Patel, N.B.; Gunther, S.; Li, C.S.; Liu, Y.; Lee, C.Y.; Kludt, N.A.; Patel, K.B.; Ali, M.R.; Wong, M.S. Body Image \& Quality of Life: Changes With Gastric Bypass and Body Contouring. Ann. Plast. Surg. 2016, 76 (Suppl. 3), S216-S221. [CrossRef] [PubMed]

88. Jumbe, S.; Hamlet, C.; Meyrick, J. Psychological Aspects of Bariatric Surgery as a Treatment for Obesity. Curr. Obes. Rep. 2017, 6, 71-78. [CrossRef]

89. Hameed, S.; Salem, V.; Tan, T.M.; Collins, A.; Shah, K.; Scholtz, S.; Ahmed, A.R.; Chahal, H. Beyond Weight Loss: Establishing a Postbariatric Surgery Patient Support Group-What Do Patients Want? J. Obes. 2018, 2018, 8419120. [CrossRef] [PubMed]

90. Biörserud, C.; Shams, K.; Elander, A.; Fagevik Olsén, M. Self-image after bariatric surgery and its relationship to gender, excess skin and health-related quality of life. J. Plast. Surg. Hand Surg. 2018, 52, 288-293. [CrossRef]

91. Masheb, R.M.; Grilo, C.M.; Burke-Martindale, C.H.; Rothschild, B.S. Evaluating oneself by shape and weight is not the same as being dissatisfied about shape and weight: A longitudinal examination in severely obese gastric bypass patients. Int. J. Eat Disord. 2006, 39, 716-720. [CrossRef] [PubMed]

92. Frederick, D.A.; Garcia, J.R.; Gesselman, A.N.; Mark, K.P.; Hatfield, E.; Bohrnstedt, G. The Happy American Body 2.0: Predictors of affective body satisfaction in two U.S. national internet panel surveys. Body Image 2020, 32, 70-84. [CrossRef] [PubMed]

93. Karazsia, B.T.; Murnen, S.K.; Tylka, T.L. Is body dissatisfaction changing across time? A cross-temporal meta-analysis. Psychol. Bull. 2017, 143, 293-320. [CrossRef] [PubMed] 
94. Frederick, D.A.; Buchanan, G.M.; Sadehgi-Azar, L.; Peplau, L.A.; Haselton, M.G.; Berezovskaya, A.; Lipinski, R.E. Desiring the muscular ideal: Men's body satisfaction in the United States, Ukraine, and Ghana. Psychol. Men Masc. 2007, 8, 103-117. [CrossRef]

95. Swenson, A.R.; Allen, K.R. My shape: Young men's perceptions of their relationship to their bodies. Psychol. Men Masc. 2019, 20, 585-593. [CrossRef]

96. Tylka, T.L. No harm in looking, right? Men's pornography consumption, body image, and well-being. Psychol. Men Masc. 2015, 16, 97-107. [CrossRef]

97. Richard, A.; Rohrmann, S.; Lohse, T.; Eichholzer, M. Is body weight dissatisfaction a predictor of depression independent of body mass index, sex and age? Results of a cross-sectional study. BMC Public Health 2016, 16, 863. [CrossRef] [PubMed]

98. Gall, K.; van Zutven, K.; Lindstrom, J.; Bentley, C.; Gratwick-Sarll, K.; Harrison, C.; Lewis, V.; Mond, J. Obesity and emotional well-being in adolescents: Roles of body dissatisfaction, loss of control eating, and self-rated health. Obesity 2016, 24, 837-842. [CrossRef]

99. Schvey, N.A.; Sbrocco, T.; Bakalar, J.L.; Ress, R.; Barmine, M.; Gorlick, J.; Pine, A.; Stephens, M.; Tanofsky-Kraff, M. The experience of weight stigma among gym members with overweight and obesity. Stigma Health 2017, 2, 292-306. [CrossRef]

100. Puhl, R.M.; Himmelstein, M.S.; Pearl, R.L. Weight stigma as a psychosocial contributor to obesity. Am. Psychol. 2020, 75, 274-289. [CrossRef]

101. Tylka, T.L.; Annunziato, R.A.; Burgard, D.; Daníelsdóttir, S.; Shuman, E.; Davis, C.; Calogero, R.M. The Weight-Inclusive versus Weight-Normative Approach to Health: Evaluating the Evidence for Prioritizing Well-Being over Weight Loss. J. Obes. 2014, 2014, 983495. [CrossRef]

102. Cox, A.E.; Ullrich-French, S.; Tylka, T.L.; McMahon, A.K. The roles of self-compassion, body surveillance, and body appreciation in predicting intrinsic motivation for physical activity: Cross-sectional associations, and prospective changes within a yoga context. Body Image 2019, 29, 110-117. [CrossRef]

103. Masters, W.H.; Johnson, V.E. Human Sexual Response; Little, Brown: Boston, MA, USA, 1966.

104. Meana, M. Sexual Dysfunction in Women; Hogrefe Publishing: Cambridge, MA, USA, 2012.

105. Kaplan, H.S. Disorders of Sexual Desire and Other New Concepts and Techniques in Sex Therapy; Brunner/Mazel: New York, NY, USA, 1979; Volume 2.

106. Kaplan, H.S. Sexual Desire Disorders: Dysfunctional Regulation of Sexual Motivation; Routledge: New York, NY, USA, 1995.

107. Basson, R. The female sexual response: A different model. J. Sex Marital Ther. 2000, 26, 51-65. [CrossRef] [PubMed]

108. Basson, R.; Brotto, L.A.; Laan, E.; Redmond, G.; Utian, W.H. Assessment and Management of Women's Sexual Dysfunctions: Problematic Desire and Arousal. J. Sex. Med. 2005, 2, 291-300. [CrossRef]

109. Bancroft, J.; Graham, C.A. The varied nature of women's sexuality: Unresolved issues and a theoretical approach. Horm. Behav. 2011, 59, 717-729. [CrossRef] [PubMed]

110. Bancroft, J.; Janssen, E. The dual control model of male sexual response: A theoretical approach to centrally mediated erectile dysfunction. Neurosci. Biobehav. Rev. 2000, 24, 571-579. [CrossRef]

111. Janssen, E.; Vorst, H.; Finn, P.; Bancroft, J. The Sexual Inhibition (SIS) and Sexual Excitation (SES) Scales: I. Measuring sexual inhibition and excitation proneness in men. J. Sex Res. 2002, 39, 114-126. [CrossRef] [PubMed]

112. Bancroft, J.; Graham, C.A.; Janssen, E.; Sanders, S.A. The dual control model: Current status and future directions. J. Sex Res. 2009, 46, 121-142. [CrossRef]

113. Milhausen, R.R.; Graham, C.A.; Sanders, S.A.; Yarber, W.L.; Maitland, S.B. Validation of the Sexual Excitation/Sexual Inhibition Inventory for Women and Men. Arch. Sex. Behav. 2010, 39, 1091-1104. [CrossRef]

114. Busby, D.M.; Leonhardt, N.D.; Leavitt, C.E.; Hanna-Walker, V. Challenging the standard model of sexual response: Evidence of a variable male sexual response cycle. J. Sex Res. 2020, 57, 848-859. [CrossRef]

115. Leavitt, C.E.; Leonhardt, N.D.; Busby, D.M. Different ways to get there: Evidence of a variable female sexual response cycle. J. Sex Res. 2019, 56, 899-912. [CrossRef]

116. Ghane, A.; Sweeny, K. Embodied health: A guiding perspective for research in health psychology. Health Psychol. Rev. 2013, 7 , S159-S184. [CrossRef]

117. Rowland, D.L.; Motofei, I. Cross Cultural Research: Opportunities and Strategies for Discovery. In Cultural Differences and the Practice of Sexual Medicine: A Guide for Sexual Health Practitioners; Rowland, D.L., Jannini, E.A., Eds.; Springer International Publishing: Cham, Switzerland, 2020.

118. Çaynak, S.; Boyacıŏlu, N.E.; Temel, M. Body perception and sexuality of bariatric surgery patients. Perspect. Psychiatr. Care 2021, 57, 1266-1272. [CrossRef]

119. Nilsson-Condori, E.; Järvholm, S.; Thurin-Kjellberg, A.; Hedenbro, J.; Friberg, B. A New Beginning: Young Women's Experiences and Sexual Function 18 Months After Bariatric Surgery. Sex. Med. 2020, 8, 730-739. [CrossRef]

120. Kinzl, J.F.; Trefalt, E.; Fiala, M.; Hotter, A.; Biebl, W.; Aigner, F. Partnership, sexuality, and sexual disorders in morbidly obese women: Consequences of weight loss after gastric banding. Obes. Surg. 2001, 11, 455-458. [CrossRef]

121. Kolotkin, R.L.; Binks, M.; Crosby, R.D.; Østbye, T.; Gress, R.E.; Adams, T.D. Obesity and sexual quality of life. Obesity 2006, 14, 472-479. [CrossRef] [PubMed]

122. Morotti, E.; Battaglia, B.; Paradisi, R.; Persico, N.; Zampieri, M.; Venturoli, S.; Battaglia, C. Body mass index, Stunkard Figure Rating Scale, and sexuality in young Italian women: A pilot study. J. Sex. Med. 2013, 10, 1034-1043. [CrossRef] 
123. McHugh, M.; Kasardo, A. Anti-fat Prejudice: The Role of Psychology in Explication, Education and Eradication. Sex Roles 2012, 66, 617-627. [CrossRef]

124. Dickins, M.; Thomas, S.L.; King, B.; Lewis, S.; Holland, K. The role of the fatosphere in fat adults' responses to obesity stigma: A model of empowerment without a focus on weight loss. Qual. Health Res. 2011, 21, 1679-1691. [CrossRef] [PubMed]

125. Dickins, M.; Browning, C.; Feldman, S.; Thomas, S. Social inclusion and the Fatosphere: The role of an online weblogging community in fostering social inclusion. Sociol. Health Illn. 2016, 38, 797-811. [CrossRef]

126. O'Hara, L.; Ahmed, H.; Elashie, S. Evaluating the impact of a brief Health at Every Size ${ }^{\circledR}$-informed health promotion activity on body positivity and internalized weight-based oppression. Body Image 2021, 37, 225-237. [CrossRef]

127. Neumark-Sztainer, D. The weight dilemma: A range of philosophical perspectives. Int. J. Obes. Relat. Metab. Disord. J. Int. Assoc. Study Obes. 1999, 23 (Suppl. 2), S31-S37. [CrossRef] [PubMed]

128. Penney, T.L.; Kirk, S.F.L. The Health at Every Size paradigm and obesity: Missing empirical evidence may help push the reframing obesity debate forward. Am. J. Public Health 2015, 105, e38-e42. [CrossRef] [PubMed]

129. Sabatini, F.; Ulian, M.D.; Perez, I.; Pinto, A.J.; Vessoni, A.; Aburad, L.; Benatti, F.B.; Lopes de Campos-Ferraz, P.; Coelho, D.; de Morais Sato, P.; et al. Eating Pleasure in a Sample of Obese Brazilian Women: A Qualitative Report of an Interdisciplinary Intervention Based on the Health at Every Size Approach. J. Acad. Nutr. Diet. 2019, 119, 1470-1482. [CrossRef] [PubMed]

130. Provencher, V.; Bégin, C.; Tremblay, A.; Mongeau, L.; Corneau, L.; Dodin, S.; Boivin, S.; Lemieux, S. Health-At-Every-Size and eating behaviors: 1-year follow-up results of a size acceptance intervention. J. Am. Diet. Assoc. 2009, 109, 1854-1861. [CrossRef]

131. Forman, E.M.; Butryn, M.L.; Manasse, S.M.; Crosby, R.D.; Goldstein, S.P.; Wyckoff, E.P.; Thomas, J.G. Acceptance-based versus standard behavioral treatment for obesity: Results from the mind your health randomized controlled trial. Obesity 2016, 24, 2050-2056. [CrossRef]

132. Berman, M.; Morton, S.; Hegel, M. Health at Every Size and Acceptance and Commitment Therapy for Obese, Depressed Women: Treatment Development and Clinical Application. Clin. Soc. Work J. 2016, 44, 265-278. [CrossRef]

133. Yilmaz, F.T.; Kumsar, A.K.; Demirel, G. The effect of body image on sexual quality of life in obese married women. Health Care Women Int. 2019, 40, 479-492. [CrossRef]

134. Parchomiuk, M.; Kirenko, J. Sexual Satisfaction in Obese People. Sex. Cult. 2021, 25, 1588-1604. [CrossRef]

135. Satinsky, S.; Dennis, B.; Reece, M.; Sanders, S.; Bardzell, S. My 'Fat Girl Complex': A preliminary investigation of sexual health and body image in women of size. Cult. Health Sex. 2013, 15, 710-725. [CrossRef]

136. Kvalem, I.L.; Træen, B.; Markovic, A.; von Soest, T. Body Image Development and Sexual Satisfaction: A Prospective Study From Adolescence to Adulthood. J. Sex Res. 2019, 56, 791-801. [CrossRef] [PubMed]

137. Sarwer, D.B.; Steffen, K.J. Quality of Life, Body Image and Sexual Functioning in Bariatric Surgery Patients. Eur. Eat. Disord. Rev. 2015, 23, 504-508. [CrossRef] [PubMed]

138. Szymanski, D.M.; Moffitt, L.B.; Carr, E.R. Sexual Objectification of Women: Advances to Theory and Research 1భ7. Couns. Psychol. 2010, 39, 6-38. [CrossRef]

139. Steer, A.; Tiggemann, M. The Role of Self-Objectification in Women's Sexual Functioning. J. Soc. Clin. Psychol. 2008, 27, 205-225. [CrossRef]

140. Gillen, M.M.; Markey, C.H. A review of research linking body image and sexual well-being. Body Image 2019, 31, $294-301$. [CrossRef] [PubMed]

141. Carels, R.A.; Miller, J.C.; Hlavka, R.; Selensky, J.; Shonrock, A.M.T.; Ellis, J.M. Associations between husbands' weight bias and related concerns and husbands' and wives' psychological and relationship outcomes. Body Image 2020, 35, 11-21. [CrossRef] 